\title{
SIGNS OF IMPENDING CALVINGIN BEEF COWS UNDER VARIOUS FEEDING AND HOUSING CONDITIONS
}

A. N. UGNIVENKO, Doctor of Agricultural Sciences, Professor, Head of the Department of Dairy and Beef Production Technology, ORCID: https://orcid.org/0000-0001-6278-8399

G. P. BONDARENKO, Candidate of Agricultural Sciences, Associate Professor

of the Department of Dairy and Beef Production Technology, ORCID: https://orcid.org/0000-0001-6225-5015

D. K. NOSEVYCH, Candidate of Agricultural Sciences, Associate Professor

of the Department of Dairy and Beef Production Technology, ORCID: https://orcid.org/0000-0003-2495-2084

National University of Life and Environmental Sciences of Ukraine

S. YU. DEMCHUK, Candidate of Veterinary Sciences, leading researcher

of Reproduction Biotechnology laboratory, ORCID: https://orcid.org/0000-0002-4708-0955

Institute of Animal Breeding and Genetics

E-mail:ugnivenko@nubip.edu.ua, livestock-solutions@ukr.net, dknosevich@i.ua, stepandimchuk@gmail.com

\begin{abstract}
Research data on the signs of impending calving in late pregnant cows of Ukrainian beef breed under various systems of housing and feeding are presented in the paper. Tie stall housing provides for earlier development of calving signs in cows three weeks prior to calving. Cervical plug is dissolved 5,1 days prior to calving, dilatation of pelvic ligaments occurs at 3,1 days before calving, udder edema -5 days, vulva extension $-7,5$ days prior to calving. Those signs develop later in grazing conditions. Cervical plug is dissolved 2,0 days prior to calving, dilatation of pelvic ligaments occurs at 2,3 days before calving, udder edema - 2,5 days, vulva extension-0,9 days prior to calving. As compared to cows, heifers develop calving signs earlier.

Keywords: calving signs, beef cows, housing systems, nutrition level
\end{abstract}

\section{Introduction.}

As calving time approaches, the body of the cows undergoes several changes related to the coming parturition [9]. They are known assigns of impending calving. In accurate etection of the sesigns results in increase of dystocia casesin females. Dystocia can have a large economic impact on producers due to calf death [10], high veterinary costs and cow deaths [2], high percentage of metritis [1], that impairs reproductive performance of cows [7]. The signs do not indicate the calving process 
they just predict emerging calving. Those signs include extended udder and vulva, dilatation of the pelvic ligaments, dissolving of cervical plug etc. Vestibule of vagina increases in size and got swelled prior to calving. As parturition approaches the tension of its' walls reduces and it becomes flabby and motile. Swollen vulva is not exact sign of immediate calving, its puffiness and hyperemia occurs in various cows very far or several hours from calving.

\section{Analysis of recent researches and publications.}

Status of cervix is thebest indicator of impending calving start. Several days before calving it is either closed or allows forefinger to go through by $2,0-2,5 \mathrm{~cm}$. Cervix is filled with a mucus plug. After this plug dissolved the cervix channel begins to open. Special condition of sacrosciatic ligaments is another reliable indicator of the coming parturition. They start to relax several days before calving, reducing tension of rump muscles. Thickness of these ligaments can be palpated when they form a 2,5 cm cavity. In some cases significant relaxation of ligaments occurs 1 to 11 days before calving. If body condition score of the cow exceeds 7 points, she may not demonstrate relaxation of pelvic ligaments, although cows with moderate body condition demonstrate relaxation of ligaments 12-24 hours before calving [9]. Swollen tissues before calving is a result of high level of estrogen and histamine. Increased production of prostaglandin F2-alpha leads to luteolisis and release of relaxin from the corpus luteum that provokes swelling and relaxation of the pelvic ligaments [4].

There is no single opinion regarding the signs of impending calving in females of dairy and dual purpose breeds.

Swelling and hyperemia of vulva in Black and White Holstein cows occurs
2,9 days prior to calving, relaxation of the rump ligaments takes place 2,8 days prior to calving, dissolving and excretion of the cervix plug $-8,9$ days, udder edema -3 days before calving [6]. As to the pelvic ligament dilatation, this process shows big vari ability [5], extending up to $1 / 3-1 / 4$ of its initial length 2 days before parturition. Tail head ligaments demonstrate relaxation from 12-24 to 36 hours prior to calving [3].

Beef cattle farming is being established in Ukraine. Beef farmers are familiar with the signs of impending calving, although they do not observe the cows often enough and are not able to predict their calving time. Reproductive performance is the main production trait in beef farming. There is very limited data that explains development of calving signs in cows under various housing systems and feeding conditions that could be utilized for optimization of extensive production technology.

That is why the purpose of this research was studying the terms of development of signs of impending calving in beef females under various housing and feeding conditions.

\section{Materials and methods.}

Research was conducted on the females of Ukrainian beef and Chianina breeds located at the purebred operation "Volia" Cherkasy oblast. We examined the cows for 3 weeks prior to expected calving trying to detect the development of the signs of impending calving in cows of Ukrainian Beef Breed under various housing systems.

Four groups of females were selected aging from 4 to 7 years. The cows of the group 1 (I group - control group) were kept in tie stalls before, during and after calving. The cows of group 2 (II group) were kept in outdoor pens prior to calving. 
They were moved to the calving area at 15-20 days before expected calving date. Theycalvedinthecalving pens $(3,5 \times 3,0$ $\mathrm{m})$. They were moved from the calving area one month after calving. The cows of group 3 (III group) were kept in outdoor pens. 15-20 daysbefore calving they were moved in stalls at the calving area and immediately before calving they were moved into calving pens $(3,5 \times 5,0 \mathrm{~m})$. Three day safter calving they went in to separate paninside the barn. The cows of group 4 (IV group) were grazing pastures on summer. 10-15 daysbeforeexpectedcalvingdatetheyweremovedinto separate pen with a roof. The calves were separated from their dams 2-3 days after parturition and cows had access to grazing.

The influence of different feeding levels on development of calving signs in late pregnant cows $(n=30)$ and heifers $(n=12)$ of Chianina breed was studied in "Terezine" farm. Females were equally separated into control and experimental groups. Females from the control group obtained the rations which were $21 \%$ lower than nutrient requirements. The level of nutrition was higher in experimental groups as compared to the control groups during the last four months of gestation. The cows obtained the ration that corresponded to requirement, whereas heifers obtained the ration $38 \%$ higher than requirement. Amount of feeds per cow per day were equivalent to 8,55 oat feed units in experimental groups and 6,03 oat feed units in the control group. Each oat feed unit was supplied with 83-87 grams of digestible protein. Increase of the nutrient level in experimental groups by 2,52 units was achieved through additional feeding them $3 \mathrm{~kg}$ of hay and $1 \mathrm{~kg}$ of concentrates.

Heifers included in experimental and control groups had 408 and $416 \mathrm{~kg}$ live weight at insemination, and at the moment of the trial beginning their liveweight was
483 and $482 \mathrm{~kg}$ respectively. Age of heifers at calving was 25,5 months. Pregnant heifers were given regular access to outdoor pens for up to 3 hours per day. Indoor pens of 10 square meters size have been used for calving. 10-15 days after calving all cows have been kept in one group and allowed a balanced ration according to their nutrient requirements.

Arithmetic mean $(\mathrm{M})$, mean error $( \pm$ $m$ ) and reliability of intergroup variation (td)were calculated according to standard methodology [8].

\section{Results of research, analysis and discussion.}

Tie stall housing system of cows (I group) lead to earlier administration of calving signs as compared to other housing systems. Cervical plug dissolved from 2,5 to 2,63 times earlier, dilatation of the pelvic ligaments occurred $18,6 \%$ to $50,5 \%$ earlier, udder edema occurred 15,6 to 2,02 times and vulva swelling occurred 3,0 to 8,2 times earlier (table 1). Increase of external genitals was more significant.

This could be explained by comfort deficiency when keeping animals in tie stalls (lack of light, high or low temperature, high humidity, high concentration of ammonia and other harmful gases) that made negative impact on reproductive function of a cow. The negative impact of these factors combination is complicated by the lack of access of animals to outdoor pens, that reduce the general tonus of the body, decrease nutrients adsorption, interferes vitamin $\mathrm{E}$ synthesis. Lack of solar light can be considered as significant complication of animal housing, that result in appetite reduction, depression of body functions and decrease of general resistance of the body against various pathogens, as well as reduced estrus. Long lasting hypodinamia depresses homeostasis and regulatory functions of 


\section{Occurrence of calving signs (days) in cows under various housing systems}

$$
(M \pm m)
$$

\begin{tabular}{|l|l|l|l|l|l|}
\hline \multirow{2}{*}{ Group } & \multirow{2}{*}{$\mathrm{n}$} & \multicolumn{4}{|c|}{ Time of calving signs development, days } \\
\cline { 3 - 6 } & & $\begin{array}{c}\text { Cervical plug } \\
\text { dissolving }\end{array}$ & $\begin{array}{c}\text { Pelvic ligaments } \\
\text { dilatation }\end{array}$ & Udder edema & $\begin{array}{c}\text { Swelling of } \\
\text { external genitals }\end{array}$ \\
\hline I & 23 & $5,1 \pm 0,55$ & $3,1 \pm 0,35$ & $5,0 \pm 0,50$ & $7,5 \pm 0,49$ \\
\hline II & 24 & $2,1 \pm 0,23 * * *$ & $2,6 \pm 0,33$ & $4,4 \pm 0,32$ & $2,5 \pm 0,36 * * *$ \\
\hline III & 25 & $2,0 \pm 0,36 * * *$ & $2,1 \pm 0,35 * *$ & $3,3 \pm 0,52 *$ & $2,2 \pm 0,26 * * *$ \\
\hline IV & 22 & $2,0 \pm 0,18 * * *$ & $2,3 \pm 0,27 * *$ & $2,5 \pm 0,35^{* *}$ & $0,9 \pm 0,09 * * *$ \\
\hline
\end{tabular}

Notes: * $-\mathrm{P}<0,05 ; * *-\mathrm{P}<0,01 ; * * *-\mathrm{P}<0,001$

the body, that result in reduced production of follicle stimulating hormone (FSH), important metabolite of hypothalamohypophysial system. Its deficiency slows down follicle development. Stagnation events in organs and tissues negatively impacts their functionality and depresses all metabolic processes. Keeping cows on grasslands in combination with active exercise leads to the poorest development of calving signs. Udder edema is observed only in 18,2\% of cows, on average 2,5 days before calving. Swollenness of vulva, although clearly visible, are limited and not prominent. As to the other signs of impending calving they can be detected at following terms: cervical plug dissolving - 2 days, dilatation of pelvic ligaments $-2,3$ days before calving.

Solar radiation is an important biological factor pf reproductive performance. It influence metabolic processes in the body, increases oxygen consumption and excretion of water and carbon dioxide, improves digestion system and other systems pf the body. This has a positive impact on animal health and fertility. Regular exercise positively influences animal reproductive functions. Muscle activity is a single way of activation of body functions in peri-parturient females. The load on heart and circulatory system is reduced, that allows for better blood supply to organs. Muscle activity improves function of the reproductive system. Better blood supplyhelps to dissolve degenerated muscle fibers. In addition to nutrition, air quality is one of the most important environmental factors. It influences metabolic processes, heat regulation, gas exchange, physical and chemical parameters of blood, core temperature and skin temperature etc. This affects animal health and performance, their resistance to disease. Only healthy animal may have a high reproductive performance.

As compared to tie stall and pasture housing system, loose hosing of cows before, during and after calving, results in intermediate terms of calving signs development. Dissolving of cervical plug occurs 3,08 days later than in tie stalls, dilatation of pelvic ligaments occurs 0,49 days later, udder edema $-0,68$ days later, swollenness of vulva $-4,98$ days later. Loose housing of cows and keeping them 15-20 days before expected calving in pens inside the cow barns, calving in separate boxes of 3,5 x 5,0 meters size, leads to 3,1 days later dissolving of cervical plug, dilatation of pelvic ligaments occurs 1,0 day later, udder edema occurs 1,7 days later and swollenness of vulva occurs 5,3 days later as compared to tie stall housing system. Only $46 \%$ of those cows demonstrated udder edema. This is related 


\section{Terms of development (days) of calving signs in cows and heifers of Chianina breed $(M \pm m)$}

\begin{tabular}{|l|c|c|c|}
\hline \multirow{2}{*}{ Calving sign } & \multicolumn{2}{|c|}{ Group of females } & \multirow{2}{*}{ td } \\
\cline { 2 - 3 } & heifers $(\mathrm{n}=12)$ & cows $(\mathrm{n}=30)$ & \\
\hline Cervical plug dissolving & $6,5 \pm 0,41$ & $2,0 \pm 0,25$ & $4,5^{* * *}$ \\
\hline Pelvic ligaments dilatation & $5,1 \pm 0,64$ & $2,4 \pm 0,25$ & $2,7 * * *$ \\
\hline Udder edema & $6,4 \pm 0,34$ & $4,2 \pm 0,30$ & $2,2 * * *$ \\
\hline Swelling of vulva & $4,3 \pm 0,88$ & $2,5 \pm 0,30$ & $1,8^{*}$ \\
\hline
\end{tabular}

Notes: * - $\mathrm{P}<0,05, * * *$ - $\mathrm{P}<0,001$

to shorter term of their housing in calving area and restricted mobility of those cows.

Heifers of Chianina breed demonstrate earlier development of calving signs as compared to the cows (table 2). Dissolving of cervical plug in heifers occurs on average 6,5 days before expected calving, pelvis transformation -5 days, udder edema - 6,4 days, genital swelling $-4,3$ days. In cows, dissolving of cervical plug occurs on average 6,5 days later, pelvis transformation $-2,7$ days later, udder edema $-2,2$ days later, genital swelling $-1,8$ days later as compared to heifers.

\section{Conclusions.}

The earliest development of calving signs in cows of Ukrainian beef breed has been observedin tie-stall housing system, while grazing animals were characterized by the latest development of calving signs. Housing of cows in free stalls combined with keeping them in group pens inside the barn 15-20 days prior to calving followed by calving in the calving pens 3,5 $\mathrm{x} 5,0 \mathrm{~m}$ resulted in reduced terms of calving signs development as compared to the cows in tie-stalls and increased terms as compared to the cows on pastures. Heifers of Chianina breed developed the signs of impending calving earlier as compared to the cows of this breed.

\section{References}

1. Benzaguen, M. E., Risco, G. A., Archbald, L. F., Melendez, Z. P., Thatcher, M. I., Thatcher, W. W. (2007). Rectal temperature, calving-related factors, and the incidence of puerperal metritis in postpartum dairy cows. J. Dairy Science, 90, 2804-2814.

2. Dee Whittier, W., Nancy, M., Currin, John, F. Currin, John, B. Hall. (2009). Calving Emergencies in Beef Cattle: Identification and Prevention. Publications and Educational Resources. Available at: https://pubs.ext. vt.edu/400/400-018/400-018.html.

3. Goncharov, V. H., Karpov, V. A. (1991). Profilaktika i lechenie ginekologicheskikh zabolevaniy u korov. 2-e izdanie, peresmotrennoe [Prevention and treatment of gynaecological disorders in cows. 2nd Edition, revised]. Moscow, Russia: Rosagropromizdat, 190.

4. Grun, E. (1985). Neue Einblicke in die biologischen Wirkungen und die physiologische Roledes Relaxinsbei Haustieren. Arch. exp. Veterinarmedicin, 6, 874-883.

5. Kalinovskii, G. N. (1992). Fiziolohichne znachennia lobkovo-skretkovoho spletinnia pry otelenni. Diahnostyka, profilaktyka ta likuvannia khvorob na spetsializovanykh fermakh [Physiological importance of lumbosacral plexus at calving. Diagnostics, prevention and treatment of deceases at specialized farms]. Proceedings of Ukrainian Agricultural Academy, 67-69. 
6. Koreiba, L. V. (2017). Characteristics of gestation, calving and post-calving period in black and white Holstein cows under conditions of PLC "Agro-Soyuz" Sinelnikovskii rayon Dnipropetrovsk oblast. World of Science, 48 (2), 84-88.

7. Piccardi, M., Romero, G., Veneranda, G., Castello, E., Romero, D., Balzarini, M., Bo, G. A. (2015). Effect of puerperal metritis on reproductive and productive performance in dairy cows in Argentina. Theriocenology, 85 (5), 887-893. DOI: 10.1016/j. theriogenology. 2015.10.038.

8. Plohinskiy, N. A. (1961). Biometriya [Biometrics]. Novosibirsk, 364.
9. Rasby, R. (2008). Know the Signs of Impending Calving in Cows or Heifers. Institute of Agriculture and Natural Resources University of Nebraska-Lincoln. NUNL Beef. Available at: https://beef.unl.edu/ cattleproduction/impending2008.

10. Selk, G. (2018). Calving Time Management for Beef Cows and Heifers. Oklahoma Cooperative Extension Service. OSU Extension Fact Sheets. Available at: http:// factsheets.okstate.edu/documents/e1006-calving-time-management-for-beefcows-and-heifers/.

\section{А. М. Угнівенко, Г. П. Бондаренко, Д. К. Носевич, С. Ю. Демчук (2019). ТЕРМІНИ ПОЯВИ ПРОВІСНИКІВ РОДІВ У КОРІВ М'ЯСНИХ ПОРІД ЗА РІЗНИХ УМОВ УТРИМАННЯ І ГОДІВЛІ. Тваринництво та технології харчових продуктів,} 10(1): 61-66. https://doi.org/

Анотація. Під часотелення корови повиннізнаходитись під спостереженням, що дозволяє вчасно надати необхідну допомогу їм або приплоду. Через високу мінливість тривалості тільності та відсутність даних про час природного парування корів на пасовищах, чітко спрогнозувати часмайбутнього отелення тяжко, томупрацівникигосподарств визначають його орієнтуючись на провісники родів. У роботі наведені дані щодо появи провісників родів у глибокотільних корів української м'ясної породи за різних умов утримання та годівлі. Для цього дібрали чотири групи самиць у віці від 4 до 7 років. Тварин першої групи утримували прив'язно до, під час, і після родів. Тварин другої групи - безприв'язно в загоні. 3а 15-20 діб до очікуваних родів їх переводили у родильне відділення зі станками 3,5 × 3,0 м з утриманням в них ще місяць після отелення. Корів і нетелей третьої групи утримували так само, як і другої, але перед отеленням їх переводили в бокси 3,5 ×5,0 м. Через три доби після родів їх випускали в окрему секцію корівника. Корови четвертої групи знаходилися літом на випасанні. 3а 10-15 діб до очікуваних родів їх відділяли в загін з накриттям.

Встановлено, що прив'язне утримання корів за три тижні до отелення призводить до більш раннього прояву у них провісників родів. зокрема розрідження слизового корка вагітності настає за 5,1 доби до отелення, розм'якшення зв'язок тазу - за 3,1, набряк вимені - за 5,0, набряк зовнішніх статевих органів - за 7,5 доби. За умов пасовищного утримання передвісники родів проявляються найпізніше. Зокрема розрідження слизового корка проявляється за 2,0 доби до родів, розм'якшення зв'язок тазу - за 2,3, набряк вимені - за 2,5, набряк зовнішніх статевих органів - за 0,9 доби. Провісники родів у нетелей появляються раніше, ніж у корів.

Ключові слова: провісники родів, м'ясні корови, система утримання, рівень годівлі 